\title{
EFFECTS OF DIFFERENT CONTROL VARIABLES ON WORKPLACE BULLYING IN ORGANIZATIONS IN SERBIA
}

\author{
UDC: $342.7: 331(497.11)$ \\ 316.62:331(497.11) \\ Original Scientific Paper \\ Sanja STANKOV ${ }^{1}$, Jasmina POŠTIN ${ }^{2}$, Marko KONJIKUŠIĆ ${ }^{3}$, \\ Aleksandra JAGODIĆ RUSIĆ ${ }^{4}$, Hadži Strahinja STOJKOVIĆ ${ }^{5}$, Edin STRUKAN ${ }^{6}$ \\ ${ }^{1}$ Republic of Serbia \\ ${ }^{2}$ University "Union - Nikola Tesla", Beograd, Faculty of Management, 21205 Sremski Karlovci, \\ Njegoševa 1a, Republic of Serbia \\ E-mail: famzr.edu@gmail.com \\ ${ }^{3}$ University “Union - Nikola Tesla”, Beograd, Faculty of Management, 21205 Sremski Karlovci, \\ Njegoševa 1a, Republic of Serbia \\ ${ }^{4}$ University "Business Academy”, Faculty of economics and engineering management, 21000 Novi Sad, \\ Cvećarska 2, Republic of Serbia \\ ${ }^{5}$ University "Business Academy", Faculty of law for commerce and judiciary, 21000 Novi Sad, \\ Geri Karolja 1, Republic of Serbia \\ ${ }^{6}$ Connecta d.o.o. Sarajevo, 71000 Sarajevo, Dzemala Bijedica 172b, Bosnia and Herzegovina
}

Paper received: 24.07.2020.; Paper accepted: 02.10.2020.

\begin{abstract}
This paper presents the results of the research of the six control variables impact on workplace bullying dimension and harassment items. Gender of respondents, Age of respondents, Education of respondents, National origin of the company, Ownership structure of the company, and Size of the company (number of employees) were used as control variables. The research was conducted through a survey with respondents, and respondents are employees in Serbian organizations, at different hierarchical levels. The sample included 536 questionnaires. T-test was applied to average ratings of the workplace bullying dimensions and and self-labelling (mistreatment) item and in compliance with the aforementioned control variables. It was indicated that workplace bullying is not present in organizations in Serbia to a large extent, but it is still higher than in some highly developed countries. The size of the company (number of employees) has been identified as the only, hence a very important factor in the emergence of workplace bullying in organizations in Serbia. Workplace bullying is more emphasized in large companies than in small ones. This phenomenon is discussed in the paper.
\end{abstract}

Keywords: Workplace bullying; Mistreatment; Control variables; Size of the company; Serbia.

\section{INTRODUCTION}

Workplace bullying is the result of a complex and dynamic process whose patterns can be found at different levels, such as organization of the work, organizational culture and climate, organizational change, reward systems, job design, and leadership (Salin, \& Hoel, 2011). The violence conducted by leaders can be viewed as a form of organizational policy (Salin, 2003). The relevance of this phenomenon is growing by constant changes in the world of work, which make the work environment more stressful than before, that there is almost no individual who has not encountered some form of abuse in their workplace, either as a perpetrator or target or as an observer (Vukelić, 2015). What is positive is that, at the same time, there are increasingly important theoretical discussions and research on this (so far insufficiently analysed) topic in Serbia, but there is also the completion of international systematic and continuous research going on, regarding this topic. 
Today, the concept of workplace bullying is most thoroughly studied at the University of Bergen in Norway (BBRG, n.d.). Their research team with research group leader Professor Einarsen (Ståle Valvatne Einarsen) is dedicated to researching abuse and harassment in the workplace, constructive and destructive leadership styles, stress and emotions in organizations, and the phenomenon of whistleblowers. They are also responsible for the development of one of the most commonly used instruments for testing workplace bullying, which has been translated and adapted into several foreign languages (Vukelić, 2015). It is a comparable, valid, and widely accepted methodology - The Negative Acts Questionnaire, NAQ (Einarsen, Hoel, \& Notelaers, 2009). The worldwide data from this questionnaire will be added to the International Database on Prevention and Risk Factors of Bullying at work, (BBRG, n.d.), where more than 60 studies have been collected so far, from about 40 countries, with more than 40,000 respondents.

One of the questions that is often asked when it comes to workplace bullying is: what are the causes of this phenomenon? According to (Tsuno et al., 2015) the main reason for the existence of workplace bullying is the distance of power between the abuser and the victim if a person with more power decides to abuse his or her power. Employees with less authority in the organization (e.g., manual workers) are more likely to become the target of harassment by people with higher authority (e.g., managers and professionals). Also, an unfavorable safety climate within the organization is a predictor of workplace bullying (Law, Dollard, Tuckey, \& Dormann, 2011; Tsuno et al., 2015), as well as a poor work environment (Hauge, Skogstad, \& Einarsen, 2007; Salin \& Hoel, 2011). Workplace bullying rates can also be affected by the context in which the organization operates (for example, the sector of activity or the size of the organization), as well as various individual and organizational factors (ArizaMontes, Muniz, Leal-Rodríguez, \& Leal-Millán, 2014).

It is of particular importance for this paper to consider the effects of individual control variables on the notion of workplace bullying. Einarsen and Skogstad (1996), in a study that included about 8,000 employees in Norway, found that multiemployee organizations, industrial organizations, and male-dominated organizations had the highest prevalence of violence and that older employees were at higher risk of victimization than younger ones.

In a study of the university staff (Björkqvist, Österman, \& Hjelt-Bäck, 1994), the results showed that women felt more exposed to violence than men, and in $25 \%$ of cases victims felt that their gender could be the reason, while no significant difference was found between the attackers and their gender. Women are more likely to perceive negative actions as more severe and, therefore, more often label them as abuse. For example, as women's personal values are more strongly associated with emotional factors, women are more likely to experience verbal abuse than physical abuse than men, while men are more likely to be bullied about their work performance. There are mixed findings that show whether the sex of the perpetrator is related to the sex of the victim.

There is support for the thesis that bullying occurs when there are extensive changes in the organization such as restructuring or planned reduction of the size of the organization (McCarthy, Sheehan, \& Kearns, 1995). When bullying occurs in smaller organizations, it is often because they are led by people with insufficient managerial skills. In smaller organizations, owners identify with the notion of power and ownership which is wrong. In this regard, it is necessary to distinguish the term "boss" from a professional manager, supervisor, leader, entrepreneur. An entrepreneur is a person who simultaneously owns and runs a company, i.e., an owner-manager. Smaller organizations consider management to be only for larger organizations, and management is seen as something that belongs or is in some way, the privilege of only large organizations. Of course, management is needed in small organizations as much as in large organizations.

This paper aims to examine the state of workplace bullying dimensions and mistreatment items in organizations in Serbia. Also, these variables were observed depending on six control variables: Gender of respondents, Age of respondents, Education of respondents, National origin of the company, Ownership structure of the company, and Size of the company (number of employees).

In previous similar studies in Serbia, no risk groups for workplace bullying were identified, based on gender, level of education and hierarchical level of employees (Petrović, Vukelić, \& Čizmić, 2017), i.e., gender, age and level of 
education (Vukelić, Čizmić, \& Petrović, 2018). However, it is certainly useful to examine some more influences on workplace bullying in organizations in Serbia, such as the National origin of the company, Ownership structure of the company, and Size of the company. The research presented in this paper was conducted in companies in Serbia, and the analyzes were performed via t-test on the average grades of the workplace bullying dimensions and self-labeling (mistreatment) item, and according to the stated control variables.

\section{THEORY AND HYPOTHESIS}

\section{Defining workplace bullying}

When the literature explores different aspects of workplace bullying, then the traits that make up the abuser, as well as what all belongs to the bullying behaviour, much is borrowed from psychology (Ferris, Zinko, Brouer, Buckley, \& Harvey, 2007). According to (Einarsen, Hoel, Zapf, \& Cooper, 2010), the concept of workplace bullying was initially explored mainly from a psychological perspective, specifically "who does what to whom; when, where, why; and with what kinds of consequences for the organization and those targeted". Later, interest in this topic began to take an interdisciplinary approach. In particular, today the concept of workplace bullying is studied from other aspects, such as management, law, medicine, and sociology.

The terms "mobbing" and "bullying" are mostly used to describe negative actions in the workplace, and the reason for the existence of two parallel terms to describe, basically, the same phenomenon is that both have shortcomings that made it difficult for researchers to accept one term and give up another (Vukelić, 2015). No matter which term is used in any cultural setting, it is actually talking about the same phenomenon. The terms also used in the English literature are: psychological terror (Leymann, 1990), harassment (Brodsky, 1976), bullying (Adams, 1992), victimization (Olweus, 1994), emotional abuse (Keashly, 1998), workplace aggression (Baron \& Neuman, 1996) and similar terms.

One of the most comprehensive definitions of workplace bullying is as follows: "Bullying in the workplace means harassment, insults and social exclusion of an individual, as well as the negative impact of these forms of behaviour on his or her execution of work assignments. In order for a certain activity, interaction or process to be labelled as bullying (mobbing), it needs to be repeated, to take place correctly over time (e.g. on a weekly basis) and to last for a certain period of time." (Einarsen et al., 2010, p. 22). This definition indicates negative behaviour between one or more perpetrators and one or more victims. Based on the above mentioned definition, Vukelić (2015) singles out as a problematic point the omission of a clearer definition of whether bullying at work also applies to abusers who are not employed in a work organization, but abuse a person in a work context. Employees may be bullied by clients, patients, customers, students or anyone else to whom they provide a service directly, as well as indirectly (e.g. phone call, e-mail). In addition to the frequency of abusive behaviour, the long-term recurrence pattern (longer than 6 months) is considered the most significant feature of the bullying concept (Ertureten, Cemalcilar, \& Aycan, 2013), while a negative act that occurred only once cannot be considered as bullying (Vartia, 1996).

\section{Types and forms of workplace bullying}

Workplace bullying can occur at any hierarchical level within a work organization (Branch, Ramsay, \& Barker, 2013). However, research shows that this is usually a downward process in a hierarchical structure, and employees in managerial positions are typical perpetrators of bullying, in $89 \%$ of cases (Namie \& Namie, 2000).

Theoretically, at the hierarchical level, a bully can be a superior person, in the same or similar position, or subordinate. Types of bullying differ vertically and horizontally. The first case of vertical bullying is from top to bottom and is the most common type of bullying in which the perpetrators are superiors and the victims are subordinates. Another case of vertical bullying is bottom-up, in a situation where an employee or group of employees (subordinates) bully a superior. A special type of vertical bullying is strategic bullying (Ferris et al., 2007), which has a special sociological significance and is one of the many mechanisms used by leaders to achieve their personal and/or organizational goals. Organizations, i.e. the top management, due to unfavourable changes (technological, economic, or organizational), decide to remove "undesirable workers", i.e. the surplus labour from the workplace, using constant reprimands, 
humiliations, or punishments as means for them to decide to leave the organization.

Rayner and Hoel (1997) developed five categories of behaviours that can influence workplace bullying:

1) destabilization (e.g. assigning meaningless tasks or continuously reminding the victim of his / her mistakes);

2) isolation (e.g., preventing access to training or intentionally withholding and storing important job-related information);

3) overwork (e.g. setting impossible deadlines or unnecessarily interfering with the victim);

4) threatening the personal position (e.g. insulting or teasing the victim); and

5) a threat to professional status (e.g. public humiliation or accusation of a victim of lack of effort).

According to Einarsen et al., (2009), negative actions are usually grouped into three components (dimensions):

- Bullying focused on work. This dimension, for example, includes ordering to perform work below the level of expertise, denial of information, excessive control, excessive workload, which cannot be performed, inability to seek the right to sick leave, vacation, etc.

- Bullying focused on personality. This dimension, for example, includes direct or indirect attacks on the personal integrity of the victim (Vukelić, 2015), such as humiliation, ridicule, spreading rumours and gossip, ignoring the opinions or attitudes of individuals, making unsavoury jokes, and the like.

- Physical intimidation. This dimension, for example, includes threats of physical violence, immediate physical violence, but also behaviours such as pointing a finger, violating personal space, blocking passages, etc.

\section{Workplace bullying and different control variables}

So far, empirical studies have shown contradictory results related to gender differences in workplace bullying exposure. Although there are these contradictory results, a tendency for greater exposure of women to this phenomenon can be observed. Salin (2018) summarized existing research and ways in which gender can influence the bullying process. He concluded that slightly higher rates of abuse among women were suggested, albeit with regional differences. For example, higher rates of violence among women exist in Finland, Ireland, Spain, Germany, Greece, and France. Furthermore, no significant differences in workplace bullying were found in Scandinavian countries, among women or men, as confirmed by some other studies (Einarsen \& Hetland, 2016; Ortega, Hogh, Pejtersen, \& Olsen, 2009). The regional impact on the occurrence of differences in the rate of gender-based violence has also been confirmed by research (Van de Vliert, Einarsen, \& Nielsen, 2013).

Miner and Eischeid (2012) believe that women, who still tend to occupy lower positions in the hierarchy of the organization and have lower social power, may therefore feel less able to defend themselves against negative actions. In Malaysia, women are more exposed to workplace bullying, compared to men (Chan et al., 2019). The same authors point out that it is important to keep in mind that workplace bullying affects not only women but also men and that gender does not alleviate the level of psychological stress experienced as a consequence of abuse. Also, Tong and Low (2012) believe that the stigma around men's mental health should be reduced and that they should be encouraged to seek help when facing both violence at work and/or anxiety and depression. This is especially important because women are more likely to recognize workplace bullying, while, when it comes to men, the victimization compromises their self-esteem (Bentley et al., 2009; Escartín, Salin, \& RodriguezCaballeira, 2011; Escartín, Salin, \& RodriguezCaballeira, 2013; Jóhannsdóttir \& Ólafsson, 2004; Salin, 2018).

The findings are also inconsistent regarding the impact of employee's age on workplace bullying. Some studies have found that both younger and older employees can be equally exposed to workplace bullying (Skuzińska, Plopa, \& Plopa, 2020; Zapf, Escartín, Einarsen, Hoel, \& Vartia, 2011). On the other hand, some studies have found a greater vulnerability in workplace bullying among older employees (Einarsen, \& Skogstad, 1996; Painter, 1991), while other studies have shown greater vulnerability in the younger employees' population (Einarsen, \& Raknes, 1997; Paoli, 1997; Tsuno et al., 2015).

The question of which industry has the highest risk of violence is still open (Notelaers, 2011). Nevertheless, most research seems to suggest that 
violence is greater in the public sector (public service, health, education, public assistance) (Björkqvist et al., 1994; Hoel \& Cooper, 2000; Lewis \& Gunn, 2007; Omari, 2003; Zapf, Einarsen, Hoel, \& Vartia, 2003;). According to (Mikkelsen, \& Einarsen, 2001), workplace bullying is very present in healthcare facilities. Accordingly, Yildirim and Yildirim (2007) prove that $87 \%$ of nurses in Turkey have been subjected to some form of violence, especially the ones in the public sector.

When it comes to the private sector, workplace bullying is more pronounced in manufacturing industries (Einarsen, \& Skogstad, 1996; Hubert, \& van Veldhoven, 2001). In the services sector, exposure to violence in shops (Einarsen \& Skogstad, 1996) and the hotel and catering industry seems to be most common (Mathisen, Einarsen, \& Mykletun, 2008).

In a Japanese study (Tsuno et al., 2015), the company size did not show a significant impact on workplace bullying. However, the authors of this study assume that there is a tendency for workplace bullying to be lower in larger companies, because larger companies in Japan have higher budgets, and therefore, it is more likely that fundamental measures to prevent violence in the workplace will be taken.

The paper sets out six hypotheses (one hypothesis for each control variable):

H1: There is a statistically significant difference between the average values of the workplace bullying dimensions and self-labeling items, for female and male employees.

$\mathrm{H} 2$ : There is a statistically significant difference between the average values of the workplace bullying dimensions and self-labeling items, for younger and older employees.

H3: There is a statistically significant difference between the average values of the workplace bullying dimensions and self-labeling item, for high school and faculty educated employees.

H4: There is a statistically significant difference between the average values of the workplace bullying dimensions and self-labeling items, for employees in Serbian companies and employees in foreign companies.

H5: There is a statistically significant difference between the average values of the workplace bullying dimensions and self-labeling items, for employees in state-owned companies and employees in private companies.

H6: There is a statistically significant difference between the average values of the workplace bullying dimensions and self-labeling items, for employees in small companies and employees in medium and large companies.

\section{METHOD}

\section{Survey instruments (measures)}

Workplace bullying. Workplace bullying was measured by the Negative Acts QuestionnaireRevised instrument, NAQ-R (Einarsen, et al., 2009), which was validated into Serbian in the reference (Vukelić, Čizmić, Petrović, Tenjović, \& Giorgi, 2015). The questionnaire consists of 22 items (3 dimensions: Work-related bullying, Person related bullying, and Physically intimidating bullying). Also, the analysis used the overall dimension Workplace bullying (NAQ-R total), including all 22 items. Respondents answered how often they were exposed to each item in the last six months, offering five categories of responses: "never", "occasionally", "monthly", "weekly", and "daily".

Self-labeled victim of bullying (mistreatment item). Self-labelling (mistreatment) was measured by one item, following the reference (Einarsen, et al., 2009). Respondents answered the question of whether and to what extent they were bullied at work during the last six months (before that, the they were presented with the definition of bullying). Five categories of answers were offered: "no", "yes, occasionally", "yes, several times a month", "yes, several times a week", and "yes, almost every day".

\section{Participants and data collection}

The research included organizations in Serbia, the ones where the respondents are employed. The sample included employees at different organizational levels. The research was conducted through questionnaires. The research was conducted from January through March 2020. A total of 536 fully completed questionnaires, valid for statistical processing, were collected.

Characteristics of the sample according to the observed control variables:

- There were 294 female employees (54.9\%) and 242 male employees $(45.1 \%)$ in the sample. 
- There were 319 younger employees $(59.5 \%)$ and 217 older employees (40.5\%) in the sample. According to the age of the respondents, the sample was divided into respondents who are 40 years old and younger and respondents who are over 40.

- There were 296 high school educated employees $(55.2 \%)$ and 240 faculty educated employees (44.8\%) in the sample.

- There were 444 employees in Serbian companies $(82.8 \%)$ and 92 employees in foreign companies (17.2\%) in the sample.

- There were 184 employees in state companies $(34.3 \%)$ and 352 employees in private companies $(65.7 \%)$ in the sample.

- There were 229 employees in small companies $(42.7 \%)$ and 307 employees in medium and large companies (57.3\%) in the sample. According to the size of the company (number of employees), the sample is divided into respondents who are employed in companies with 50 or fewer employees (small companies) and respondents who are employed in companies with more than 50 employees (medium and large companies).

\section{RESULTS}

\section{Descriptive statistics}

Table 1 gives the results of descriptive statistics for the workplace bullying dimensions and selflabeling items. Among other things, Table 1 gives the mean values of all dimensions and items (for the whole sample), as well as Cronbach's alpha for each dimension. Cronbach's alpha values range from 0.755 to 0.964 .

\section{T-test}

Workplace bullying dimensions and self-labeling (mistreatment) items were examined depending on the following six control variables: Gender of respondents, Age of respondents, Education of respondents, National origin of the company, Ownership structure of the company, and Size of the company (number of employees). A t-test was performed on the average grades of the workplace bullying dimensions and self-labeling (mistreatment) item, according to the stated control variables. These analyses are shown in Tables 2 to 7. This way of examining the influence of control variables is very effective and can be found in the literature, for example (Taboroši, Strukan, Poštin, Konjikušić, \& Nikolić, 2020).

In these tables, the average scores of the workplace bullying dimensions and self-labeling (mistreatment) item, in which a statistically significant difference occurs (based on the given control variable), are indicated in bold. As can be seen (in Tables 2 to 7), only one control variable has an impact on the workplace bullying dimensions: Company size (number of employees). Therefore, complete results (Group Statistics and Independent Samples Test) are given only for this variable. For other variables (Gender of respondents, Age of respondents, Education of respondents, National origin of the company, Ownership structure of the company), only a part of the results (Group Statistics) is shown, to rationalize the number of tabular views, and thus the length of this paper.

Table 1: Descriptive statistics

\begin{tabular}{|l|c|c|c|c|c|c|c|}
\hline \multicolumn{1}{|c|}{ Dimensions and item } & $\begin{array}{c}\text { Short } \\
\text { name }\end{array}$ & N & Min & Max & Mean & $\begin{array}{c}\text { Std. } \\
\text { Deviation }\end{array}$ & $\begin{array}{c}\text { Cronbach's } \\
\text { alpha }\end{array}$ \\
\hline Work-related bullying & WRB & 536 & 1.00 & 5.00 & 2.15 & .969 & 0.903 \\
\hline A person related to bullying & PRB & 536 & 1.00 & 5.00 & 1.86 & .865 & 0.948 \\
\hline Physically intimidating bullying & PIB & 536 & 1.00 & 5.00 & 1.55 & .714 & 0.755 \\
\hline Workplace bullying (NAQ-R total) & WB & 536 & 1.00 & 5.00 & 1.91 & .831 & 0.964 \\
\hline Self-labelling (mistreatment) item & SLM & 536 & 1.00 & 5.00 & 1.88 & 1.060 & - \\
\hline \multicolumn{1}{|c|}{ Valid N (listwise) } & & 536 & & & & & \\
\hline
\end{tabular}


S. Stanković $\quad$ Effects of different control variables on workplace

et al. bullying in organizations in Serbia

Table 2: T-test of average grades on workplace bullying dimensions and self-labeling (mistreatment) item, depending on the gender of the respondents

\begin{tabular}{|c|c|c|c|c|c|}
\hline \multicolumn{6}{|c|}{ Group Statistics } \\
\hline & Gender & $\mathbf{N}$ & Mean & Std. Deviation & $\begin{array}{c}\text { Std. Error } \\
\text { Mean }\end{array}$ \\
\hline \multirow{2}{*}{ WRB } & 1 Female & 294 & 2.15792 & .997515 & .058176 \\
\hline & 2 Male & 242 & 2.14109 & .936233 & .060183 \\
\hline \multirow{2}{*}{ PRB } & 1 Female & 294 & 1.85147 & .904709 & .052764 \\
\hline & 2 Male & 242 & 1.87879 & .815225 & .052405 \\
\hline \multirow{2}{*}{ PIB } & 1 Female & 294 & 1.58050 & .752282 & .043874 \\
\hline & 2 Male & 242 & 1.51102 & .663976 & .042682 \\
\hline \multirow{2}{*}{ WB } & 1 Female & 294 & 1.91203 & .868167 & .050633 \\
\hline & 2 Male & 242 & 1.91210 & .785819 & .050514 \\
\hline \multirow{2}{*}{ SLM } & 1 Female & 294 & 1.89 & 1.076 & .063 \\
\hline & 2 Male & 242 & 1.87 & 1.042 & .067 \\
\hline
\end{tabular}

Table 3: T-test of average grades on workplace bullying dimensions and self-labeling (mistreatment) item, depending on the age of the respondents ( 1 - Younger: $\leq 40$ years; 2 - Older: 40 years)

\begin{tabular}{|c|c|c|c|c|c|}
\hline \multicolumn{5}{|c|}{ Group Statistics } \\
\hline \multirow{2}{*}{ ARB } & Age & $\mathbf{N}$ & Mean & Std. Deviation & $\begin{array}{c}\text { Std. Error } \\
\text { Mean }\end{array}$ \\
\cline { 2 - 6 } & 1 Younger & 319 & 2.15898 & 1.014272 & .056788 \\
\hline \multirow{2}{*}{ PRB } & 2 Older & 217 & 2.13759 & .901713 & .061212 \\
\cline { 2 - 6 } & 1 Younger & 319 & 1.87565 & .883621 & .049473 \\
\hline \multirow{2}{*}{ PIB } & 2 Older & 217 & 1.84639 & .838001 & .056887 \\
\cline { 2 - 6 } & 1 Younger & 319 & 1.56949 & .745330 & .041730 \\
\hline \multirow{2}{*}{ WB } & 1 Younger & 217 & 1.51920 & .665713 & .045192 \\
\cline { 2 - 6 } & 2 Older & 217 & 1.92405 & .860601 & .048184 \\
\hline \multirow{2}{*}{ SLM } & 1 Younger & 319 & 1.99443 & .787705 & .053473 \\
\cline { 2 - 6 } & 2 Older & 217 & 1.83 & 1.092 & .061 \\
\hline
\end{tabular}

Table 4: T-test of average grades on workplace bullying dimensions and self-labeling (mistreatment) item, depending on the level of education of the respondents

\begin{tabular}{|c|c|c|c|c|c|}
\hline \multicolumn{6}{|c|}{ Group Statistics } \\
\hline \multirow{2}{*}{ WRB } & Education level & $\mathbf{N}$ & Mean & Std. Deviation & $\begin{array}{c}\text { Std. Error } \\
\text { Mean }\end{array}$ \\
\cline { 2 - 6 } & 1 High school & 296 & 2.09846 & .904404 & .052567 \\
\hline \multirow{2}{*}{ PRB } & 2 Faculty & 240 & 2.21429 & 1.042517 & .067294 \\
\cline { 2 - 6 } & 1 High school & 296 & 1.84093 & .795535 & .046240 \\
\hline \multirow{2}{*}{ PIB } & 2 Faculty & 240 & 1.89201 & .944133 & .060944 \\
\cline { 2 - 6 } & 1 High school & 296 & 1.54279 & .733673 & .042644 \\
\hline \multirow{2}{*}{ WB } & 2 Faculty & 240 & 1.55694 & .690305 & .044559 \\
\cline { 2 - 6 } & 1 High school & 296 & 1.88222 & .778401 & .045244 \\
\hline \multirow{2}{*}{ SLM } & 2 Faculty & 240 & 1.94886 & .892383 & .057603 \\
\cline { 2 - 6 } & 1 High school & 296 & 1.88 & 1.006 & .058 \\
\hline
\end{tabular}


S. Stanković $\quad$ Effects of different control variables on workplace

et al. bullying in organizations in Serbia

Table 5: T-test on average grades on workplace bullying dimensions and self-labeling (mistreatment) item, depending on the national origin of the company (1 - Serbia; 2 - Foreign)

\begin{tabular}{|c|c|c|c|c|c|}
\hline \multicolumn{5}{|c|}{ Group Statistics } \\
\hline \multirow{3}{*}{ WRB } & National origin & $\mathbf{N}$ & Mean & Std. Deviation & Std. Error Mean \\
\cline { 2 - 6 } & 1 Serbia & 444 & 2.13320 & .960691 & .045592 \\
\hline \multirow{2}{*}{ PRB } & 2 Foreign & 92 & 2.23292 & 1.012086 & .105517 \\
\cline { 2 - 6 } & 1 Serbia & 444 & 1.85923 & .866777 & .041135 \\
\hline \multirow{2}{*}{ PIB } & 2 Foreign & 92 & 1.88587 & .859366 & .089595 \\
\cline { 2 - 6 } & 1 Serbia & 444 & 1.53303 & .693341 & .032905 \\
\hline \multirow{2}{*}{ WB } & 2 Foreign & 92 & 1.62681 & .805722 & .084002 \\
\cline { 2 - 6 } & 1 Serbia & 444 & 1.90192 & .827136 & .039254 \\
\hline \multirow{2}{*}{ SLM } & 2 Foreign & 92 & 1.96097 & .853643 & .088998 \\
\cline { 2 - 6 } & 1 Serbia & 444 & 1.86 & 1.062 & .050 \\
\hline
\end{tabular}

Table 6: T-test of average grades on workplace bullying dimensions and self-labeling (mistreatment) item, depending on the ownership structure of the company

\begin{tabular}{|c|c|c|c|c|c|}
\hline \multicolumn{5}{|c|}{ Group Statistics } \\
\hline \multirow{2}{*}{ WRB } & $\begin{array}{c}\text { Ownership } \\
\text { structure }\end{array}$ & $\mathbf{N}$ & Mean & Std. Deviation & Std. Error Mean \\
\cline { 2 - 6 } & 1 State & 184 & 2.09783 & .801590 & .059094 \\
\hline \multirow{2}{*}{ PRB } & 2 Private & 352 & 2.17776 & 1.046591 & .055784 \\
\cline { 2 - 6 } & 1 State & 184 & 1.83288 & .762793 & .056234 \\
\hline \multirow{2}{*}{ PIB } & 2 Private & 352 & 1.87997 & .914178 & .048726 \\
\cline { 2 - 6 } & 1 State & 184 & 1.51087 & .597406 & .044041 \\
\hline \multirow{2}{*}{ WB } & 2 Private & 352 & 1.56913 & .767919 & .040930 \\
\cline { 2 - 6 } & 1 State & 184 & 1.87327 & .696398 & .051339 \\
\hline \multirow{2}{*}{ SLM } & 2 Private & 352 & 1.93233 & .893929 & .047647 \\
\cline { 2 - 6 } & 1 State & 184 & 1.81 & .924 & .068 \\
\hline
\end{tabular}

\section{DISCUSSION}

\section{Discussion of the results of descriptive statistics}

Descriptive statistics (Table 1) show that the dimensions related to workplace bullying, as well as self-labeling (mistreatment) items, have rather low values in organizations in Serbia. The highest average grade has the dimension WRB - Workrelated bullying (2.15), then the overall dimension WB - Workplace bullying (1.91), followed by SLM - Self-labelling (mistreatment) item (1.88), PRB - Person related bullying (1.86), while the lowest rating is spotted at PIB - Physically intimidating bullying (1.55). Therefore, in general, it can be concluded that employees in organizations in Serbia are not exposed to high workplace bullying, that is, workplace bullying, on average, occurs occasionally. Workplace bullying occurs most in the form of focus on the realization and achievement of the work of employees, less on the personality of employees, and the least in the form of physical inconvenience to employees. All this can be considered a favourable result.

However, more objective insight into this result is gained only through its comparison with the results of research in some other countries. Table 8 gives the values of individual workplace bullying dimensions, which were obtained in studies in several countries: Norway (Notelaers \& Einarsen, 2013), Sweden (Rosander \& Blomberg, 2019), United Kingdom (Einarsen, et al., 2009), Spain (Moreno-Jimenez, Rodriguez-Muñoz, Martínez Gamarra, \& Gálvez-Herrer, 2007), Serbia (2015 results) (Vukelić et al., 2015) and Serbia (2020 results) - given in this paper. 
Table 7: T-test of average grades on workplace bullying dimensions and self-labeling (mistreatment) item, depending on the size of the company (number of employees) (1 - Small: 50 and fewer employees; 2 - Medium and large: more than 50 employees)

\begin{tabular}{|c|c|c|c|c|c|}
\hline \multicolumn{5}{|c|}{ Group Statistics } \\
\hline & $\begin{array}{c}\text { Number of } \\
\text { employees }\end{array}$ & $\mathbf{N}$ & Mean & Std. Deviation & $\begin{array}{c}\text { Std. Error } \\
\text { Mean }\end{array}$ \\
& & & & & \\
\hline \multirow{2}{*}{ WRB } & $\mathbf{1}$ Small & $\mathbf{2 2 9}$ & $\mathbf{2 . 0 0 8 1 1}$ & $\mathbf{. 9 0 7 9 6 8}$ & $\mathbf{. 0 6 0 0 0 0}$ \\
\cline { 2 - 6 } & $\mathbf{2}$ M and L & $\mathbf{3 0 7}$ & $\mathbf{2 . 2 5 6 4 0}$ & $\mathbf{1 . 0 0 1 2 6 9}$ & $\mathbf{. 0 5 7 1 4 5}$ \\
\hline \multirow{2}{*}{ PRB } & $\mathbf{1}$ Small & $\mathbf{2 2 9}$ & $\mathbf{1 . 7 5 3 2 8}$ & $\mathbf{. 8 4 8 6 6 5}$ & $\mathbf{. 0 5 6 0 8 1}$ \\
\cline { 2 - 6 } & $\mathbf{2}$ M and L & $\mathbf{3 0 7}$ & $\mathbf{1 . 9 4 6 2 5}$ & $\mathbf{. 8 6 8 8 2 9}$ & $\mathbf{. 0 4 9 5 8 7}$ \\
\hline \multirow{2}{*}{ PIB } & $\mathbf{1}$ Small & $\mathbf{2 2 9}$ & $\mathbf{1 . 4 7 1 6 2}$ & $\mathbf{. 6 5 7 6 8 4}$ & $\mathbf{. 0 4 3 4 6 1}$ \\
\cline { 2 - 6 } & $\mathbf{2}$ M and L & $\mathbf{3 0 7}$ & $\mathbf{1 . 6 0 6 9 5}$ & $\mathbf{. 7 4 9 0 3 6}$ & $\mathbf{. 0 4 2 7 5 0}$ \\
\hline \multirow{2}{*}{ WB } & $\mathbf{1}$ Small & $\mathbf{2 2 9}$ & $\mathbf{1 . 7 9 5 9 5}$ & $\mathbf{. 8 0 3 8 1 9}$ & $\mathbf{. 0 5 3 1 1 8}$ \\
\cline { 2 - 6 } & $\mathbf{2}$ M and L & $\mathbf{3 0 7}$ & $\mathbf{1 . 9 9 8 6 7}$ & $\mathbf{. 8 4 2 0 1 7}$ & $\mathbf{. 0 4 8 0 5 6}$ \\
\hline \multirow{2}{*}{ SLM } & 1 Small & 229 & 1.82 & 1.101 & .073 \\
\cline { 2 - 6 } & 2 M and L & 307 & 1.93 & 1.028 & .059 \\
\hline
\end{tabular}

Table 7: Continuation

\begin{tabular}{|c|c|c|c|c|c|c|c|c|c|c|}
\hline \multicolumn{11}{|c|}{ Independent Samples Test } \\
\hline & & \multicolumn{2}{|c|}{$\begin{array}{l}\text { Levene's Test for } \\
\text { Equality of } \\
\text { Variances }\end{array}$} & \multicolumn{7}{|c|}{ t-test for Equality of Means } \\
\hline & & \multirow[t]{2}{*}{$\mathrm{F}$} & \multirow[t]{2}{*}{ Sig. } & \multirow[t]{2}{*}{$\mathrm{t}$} & \multirow[t]{2}{*}{ df } & \multirow[t]{2}{*}{$\begin{array}{c}\text { Sig. } \\
\text { (2-tailed) }\end{array}$} & \multirow[t]{2}{*}{$\begin{array}{c}\text { Mean } \\
\text { Difference }\end{array}$} & \multirow[t]{2}{*}{$\begin{array}{l}\text { Std. Error } \\
\text { Difference }\end{array}$} & \multicolumn{2}{|c|}{$\begin{array}{l}\text { 95\% Confidence } \\
\text { Interval of the } \\
\text { Difference }\end{array}$} \\
\hline & & & & & & & & & Lower & Upper \\
\hline \multirow{2}{*}{ WRB } & $\begin{array}{c}\text { Equal variances } \\
\text { assumed }\end{array}$ & 11.233 & .001 & -2.954 & 534 & .003 & -.248289 & .084045 & -.413389 & -.083188 \\
\hline & $\begin{array}{c}\text { Equal variances } \\
\text { not assumed }\end{array}$ & & & -2.997 & 514.072 & .003 & -.248289 & .082859 & -.411073 & -.085504 \\
\hline \multirow{2}{*}{ PRB } & $\begin{array}{c}\text { Equal variances } \\
\text { assumed }\end{array}$ & 2.196 & .139 & -2.569 & 534 & .010 & -.192979 & .075116 & -.340539 & -.045419 \\
\hline & \begin{tabular}{|c|} 
Equal variances \\
not assumed \\
\end{tabular} & & & -2.578 & 497.355 & .010 & -.192979 & .074860 & -.340059 & -.045899 \\
\hline \multirow{2}{*}{ PIB } & $\begin{array}{c}\text { Equal variances } \\
\text { assumed }\end{array}$ & 1.453 & .229 & -2.178 & 534 & .030 & -.135333 & .062123 & -.257368 & -.013298 \\
\hline & $\begin{array}{c}\text { Equal variances } \\
\text { not assumed }\end{array}$ & & & -2.220 & 519.959 & .027 & -.135333 & .060962 & -.255096 & -.015571 \\
\hline \multirow{2}{*}{ WB } & $\begin{array}{c}\text { Equal variances } \\
\text { assumed }\end{array}$ & 3.944 & .048 & -2.811 & 534 & .005 & -.202717 & .072117 & -.344384 & -.061050 \\
\hline & \begin{tabular}{|c|}
$\begin{array}{c}\text { Equal variances } \\
\text { not assumed }\end{array}$ \\
\end{tabular} & & & -2.830 & 502.934 & .005 & -.202717 & .071631 & -.343449 & -.061985 \\
\hline \multirow{2}{*}{ SLM } & $\begin{array}{c}\text { Equal variances } \\
\text { assumed }\end{array}$ & .569 & .451 & -1.173 & 534 & .241 & -.108 & .093 & -.290 & .073 \\
\hline & $\begin{array}{c}\text { Equal variances } \\
\text { not assumed }\end{array}$ & & & -1.161 & 472.174 & .246 & -.108 & .093 & -.292 & .075 \\
\hline
\end{tabular}


S. Stanković $\quad$ Effects of different control variables on workplace

et al. bullying in organizations in Serbia

Table 8: Comparison of results of mean values for workplace bullying dimensions for several different countries

\begin{tabular}{|l|c|c|c|c|c|c|}
\hline \multicolumn{1}{|c|}{ Dimensions } & $\begin{array}{c}\text { Norway } \\
(2013)\end{array}$ & $\begin{array}{c}\text { Sweden } \\
(2019)\end{array}$ & $\begin{array}{c}\text { United } \\
\text { Kingdom } \\
(2009)\end{array}$ & $\begin{array}{c}\text { Spain } \\
(2007)\end{array}$ & $\begin{array}{c}\text { Serbia } \\
(2015)\end{array}$ & $\begin{array}{c}\text { Serbia } \\
(2020)\end{array}$ \\
\hline Work-related bullying (WRB) & & & 1.97 & 1.70 & 2.56 & 2.15 \\
\hline A person related to bullying (PRB) & & & 1.21 & 1.33 & 0.97 & 1.86 \\
\hline Physically intimidating bullying (PIB) & & & 1.29 & & 1.36 & 1.55 \\
\hline Workplace bullying (NAQ-R) (WB) & 1.22 & 1.26 & 1.45 & 1.54 & 1.53 & 1.91 \\
\hline
\end{tabular}

When compared to the other results in Table 8, the results obtained in this paper no longer seem so good. The values are low, but they are significantly higher than in some other countries. It should be borne in mind here that the comparison was made with some Scandinavian and highly developed countries. Likewise, there are visible differences concerning the results for Serbia from 2015, especially in the dimension Person related bullying (PRB). All these differences can be explained by the time distance of the period of realization of the observed research, which is five years. It is possible that certain changes took place during this period. Also, differences in average values may stem from some differences in the samples themselves, which would require a more detailed analysis of both samples. In any case, it is clear that such research should be done continuously and the results and possible changes in these results should be monitored.

\section{Discussion of the results of t-test}

The results of the t-test, shown in Tables 2 to 7 , clearly show that only one control variable affects the workplace bullying dimensions. This control variable is Company size (number of employees). All other control variables (Gender of respondents, Age of respondents, Education of respondents, National origin of the company, Ownership structure of the company) do not affect the workplace bullying dimensions. Therefore, only hypothesis H6 is confirmed, while hypotheses H1, $\mathrm{H} 2, \mathrm{H} 3, \mathrm{H} 4$, and $\mathrm{H} 5$ must be rejected. Existing research, also conducted in Serbia (Petrović et al., 2017; Vukelić et al., 2018), shows similar results regarding the impact of Gender of respondents, Age of respondents, and Education of respondents on workplace bullying. Compared to other research, the results obtained in this paper are similar to research in the Scandinavian countries (Einarsen \& Hetland, 2016; Ortega et al., 2009; Salin, 2018), when it comes to the absence of variable Gender influence on workplace bullying. Similarly, the absence of the influence of variable
Age on workplace bullying coincides with the findings of the study (Skuzińska et al., 2020; Zapf et al., 2011).

Thus, statistically significant differences in the average scores for workplace bullying dimensions, occur only with the control variable Size of an enterprise (number of employees). Higher average scores for workplace bullying dimensions exist in medium and large companies in comparison to small companies. Thus, workplace bullying is more pronounced in large companies than in small companies. This result is consistent with the results of the study (Einarsen, \& Skogstad, 1996), which showed that organizations with many employees represent a more fertile ground for violence and workplace bullying. Also, research (Ariza-Montes et al., 2014) suggests the possibility of the impact of company size on workplace bullying.

The explanation for this phenomenon may be that in larger companies there are a larger number of people, and thus a much larger number of potential and actual relationships between people. Also, it is very important that in larger companies, workplace bullying is easier to hide, while in smaller companies, people know each other better and such circumstances are much easier to notice. Finally, in larger organizational systems there are more hierarchical levels, opportunities for advancement are greater, political processes in the organization are more pronounced. All of these can be favourable conditions for threats, blackmail, unfair rewards, and punishments, as well as unfair career advancement as well as career restrictions

It should be noted that the absence of statistically significant differences in average scores for workplace bullying dimensions in other control variables (and rejection of most hypotheses), does not mean a bad result of this research, but further emphasizes the importance of the size of the company on workplace bullying. It is very significant that the main potential factor for the 
occurrence of workplace bullying in organizations has been identified.

The main limitation of the research is that the results refer to companies in Serbia. However, with a high degree of certainty, it can be assumed that the results in the part of the t-test may be more widely applicable and valid in the general case.

\section{Measures to reduce workplace bullying in organizations in Serbia}

When defining specific measures and recommendations for reducing workplace bullying in organizations in Serbia, it is necessary to consider certain facts. In a study based on the analysis of a large number of existing papers (Bakator, Petrović, Borić, \& Đalić, 2019), it was shown that HRM has a positive effect on business performance. It is clear that reducing workplace bullying, as part of the overall HRM effort, would undoubtedly strengthen the company's business results. According to (Kreiner, Sajfert, Terek, \& Petrović, 2018), a leader must possess certain character traits to be successful. Hence, workplace bullying can hardly be associated with a good and successful leader. Modern business implies acceptance of the principles of Corporate Social Responsibility (CSR), such as Environmental Protection, Employee Job Satisfaction, Ethical Principles, Supporting Endangered Groups, Caring about Young People, etc. (Bogetić, Đorđević, Ćoćkalo, \& Vorkapić, 2018).

From the previous statements, it is clear that workplace bullying will hardly appear in the conditions of quality work of HRM, ethical behaviour of leaders, as well as consistent application of CSR principles. Accordingly, the following measures are proposed to mitigate and neutralize the occurrence of workplace bullying in organizations in Serbia:

- Leaders must behave ethically, encouragingly, supportively, as well as for such values to be established and nurtured in the organization.

- Organizations should behave socially responsibly and apply all the principles that describe such behaviour.

- HRM should work efficiently, effectively, objectively and fairly, for the benefit of both organizations and employees.

- Appropriate policies and procedures need to be adopted, in order to define cases of workplace bullying, abuser, victim, and whistleblower relationships. It is important to apply these rules and procedures objectively and consistently.

- It is necessary to create a climate in organizations (and even society), which has an extremely negative view of the occurrence and the slightest indication of workplace bullying.

- It is necessary to create a climate of encouragement to report possible workplace bullying, i.e., a climate that protects the victim and the perpetrator, and adequately punishes the abuser.

- Due to unfavourable results in large companies, it would be justified (and feasible due to the larger number of employees) in these companies to form a team to monitor workplace bullying. This team would submit appropriate reports in a defined period of time (for example, twice a year).

By applying these measures, not only will there be a reduction or complete elimination of workplace bullying, but it is quite certain that the safety, trust, and satisfaction of employees will be at a high level, and with all these effects, business results will be better.

\section{CONCLUSION}

Workplace bullying is not present to a large extent in organizations in Serbia, which is certainly a good result. However, it should be noted here that the results are significantly less favourable than in some other countries (the comparison was made with highly developed countries). When it occurs, workplace bullying in organizations in Serbia is most present in the part related to the work of individuals, somewhat less in the part related to the personality of individuals, and the least in the part related to physical intimidation and harassment.

Of the six control variables observed, statistically significant differences in average scores for workplace bullying dimensions occur only in the control variable Company size (number of employees). The direction of this impact is such that workplace bullying is significantly more present in medium and large companies than in small companies. In any case, the size of the company has been identified as the only, and therefore a very significant factor in the emergence of workplace bullying in organizations.

Leaders and managers in organizations in Serbia must keep in mind that workplace bullying is 
present, perhaps not to a large extent, but that it exists, and that it is less favourable than in some other countries. They also need to know the impacts on the occurrence of workplace bullying, as well as to develop mechanisms for its prevention, recognition, and sanctioning. Of course, it is recommended to apply the previously mentioned measures, to reduce workplace bullying. Special attention and caution are advised to leaders and managers in large companies.

\section{REFERENCES}

Adams, A. (1992). Holding against workplace harassment and bullying. Personnel Management, 24(10), 38-50.

Ariza-Montes, J.A., Muniz, N.M., Leal-Rodríguez, A.L., \& Leal-Millán, A.G. (2014). Workplace bullying among managers: a multifactorial perspective and understanding. International Journal of Environmental Research and Public Health, 11(3), 2657-2682. doi:10.3390/ijerph110302657

Bakator, M., Petrović, N., Borić, S., \& Đalić, N. (2019). Impact of human resource management on business performance: A review of literature. Journal of Engineering Management and Competitiveness, 9(1), 3-13.

Baron, R.A., \& Neuman, J.H. (1996). Workplace violence and workplace aggression: Evidence on their relative frequency and potential causes. Aggressive Behavior, 22(3), 161-173. doi:10.1002/(SICI)1098-2337(1996)22:3<161::AID$\mathrm{AB} 1>3.0 . \mathrm{CO} ; 2-\mathrm{Q}$

Bentley, T., Catley, B., Cooper-Thomas, H., Gardner, D., O’Driscoll, M., \& Trenberth, L. (2009). Understanding stress and bullying in New Zealand workplaces. Final report to OH\&S Steering Committee, Albany: Massey University.

Björkqvist, K., Österman, K., \& Hjelt-Bäck, M. (1994). Aggression among university employees. Aggressive Behavior, 20(3), 173-184. doi:10.1002/10982337(1994)20:3<173::AIDAB2480200304>3.0.CO; 2-D

Bogetić, S., Đorđević, D., Ćoćkalo, D., \& Vorkapić, M. (2018). Corporate social responsibility as a factor of global competitiveness. Journal of Engineering Management and Competitiveness, 8(1), 11-19.

Branch, S., Ramsay, S., \& Barker, M. (2013). Workplace bullying, mobbing and general harassment: A review. International Journal of Management Reviews, 15(3), 280-299. doi: 10.1111/j.1468-2370.2012.00339.x

Brodsky, C.M. (1976). The Harassed Worker. Toronto: Lexington Books, DC Heath and Company.

Chan, C.M.H., Wong, J.E., Yeap, L.L.L., Wee, L.H., Jamil, N.A., \& Nantha, Y.S. (2019). Workplace bullying and psychological distress of employees across socioeconomic strata: a cross-sectional study.
BMC Public Health, 19(Suppl 4): 608. doi: 10.1186/s12889-019-6859-1.

Einarsen, S., \& Hetland, J. (2016). Another look at the role of gender in workplace bullying: A representative study of exposure and reactions to workplace bullying in gender-dominated and gender-balanced occupations. The 10th Congress of the International Association of Workplace Bullying and Harassment, Auckland

Einarsen, S., \& Raknes, B.I. (1997). Harassment in the workplace and the victimization of men. Violence and Victims, 12(3), 247-263. doi:10.1891/08866708.12.3.247

Einarsen, S., \& Skogstad, A. (1996). Bullying at work: Epidemiological findings in public and private organizations. European Journal of Work and Organizational Psychology, 5(2), 185-201. doi:10.1080/13594329608414854

Einarsen, S., Hoel, H., \& Notelaers, G. (2009). Measuring exposure to bullying and harassment at work: Validity, factor structure and psychometric properties of the negative acts questionnaire-revised. Work and Stress, 23(1), 24-44. doi:10.1080/02678370902815673

Einarsen, S., Hoel, H., Zapf, D., \& Cooper, C. L. (2010). The Concept of Bullying and Harassment at Work. The European Tradition. In S. Einarsen, H. Hoel, D. Zapf \& C. L. Cooper (Eds.), Workplace Bullying: Developments in Theory, Research and Practice (pp. 3-39). London, UK: Taylor \& Francis.

Ertureten, A., Cemalcilar, Z., \& Aycan, Z. (2013). The Relationship of Downward Mobbing with Leadership Style and Organizational Attitudes. Journal of Business Ethics, 116(1), 205-216. doi:10.1007/s10551-012-1468-2

Escartín, J., Salin, D., \& Rodriguez-Caballeira, A. (2011). Exploring gender differences in conceptualizations of workplace bullying: Defining bullying and rating the severity of different acts. Journal of Personnel Psychology, 10(4), 157-165.

Escartin, J., Salin, D., \& Rodriguez-Caballeira, A. (2013). Workplace bullying or mobbing: Gender similarities and differences in its perceived severity. Revista de Psicología Social, 28(2), 211-224.

Ferris, G.R., Zinko, R., Brouer, R.L., Buckley, M.R, \& Harvey, M.G. (2007). Strategic bullying as a supplementary, balanced perspective on destructive leadership. Leadership Quarterly, 18(3), 195-206. doi:10.1016/j.leaqua.2007.03.004

Hauge, J.L., Skogstad, A., \& Einarsen, S. (2007). Relationships between stressful work environments and bullying:results of a large representative study. Work and Stress, 21(3), 220-242. doi:10.1080/02678370701705810

Hoel, H., \& Cooper, C.L. (2000). Destructive conflict and bullying at work, Launch of the Civil Service Race Equality Network (pp. 1-30). Manchester: Manchester School of Management, University of Manchester Institute Science and Technology. 
S. Stanković $\quad$ Effects of different control variables on workplace

et al. bullying in organizations in Serbia

Hubert, A., \& van Veldhoven, M. (2001). Risk sectors for undesirable behaviour andmobbing. European Journal of Work and Organizational Psychology, 10(4), 415-424. doi:10.1080/13594320143000799

Jóhannsdóttir, H.J., \& Ólafsson, R.F. (2004). Coping with bullying in the workplace: The effect of gender, age and type of bullying. British Journal of Guidance \& Counselling, 32(3), 319-333. doi:10.1080/03069880410001723549

Keashly, L. (1998). Emotional abuse in the workplace. Journal of Emotional Abuse, 1(1), 85-117.

Kreiner, J., Sajfert, D., Terek, E., \& Petrović, N. (2018). Determination of personality traits and character of leaders, their selection and efficiency in the textile industry. Journal of Engineering Management and Competitiveness, 8(2), 121-128.

Law, R., Dollard, M.F., Tuckey, M.R., \& Dormann, C. (2011). Psychosocial safety climate as a lead indicator of work-place bullying and harassment, job resources, psychological health and employee engagement. Accident Analysis and Prevention, 43(5), 1782-1793. doi:10.1016/j.aap.2011.04.010

Lewis, D., \& Gunn R. (2007). Workplace bullying in the public sector: Understanding the racial dimension. Public Administration, 85(3), 641-665. doi:10.1111/j.1467-9299.2007.00665.x

Leymann, H. (1990). Mobbing and psychological terror at workplaces. Violence and Victims, 5(2), 119-126.

Mathisen, G. E., Einarsen, S., \& Mykletun, R. (2008). The occurrences and correlates of bullying and harassment in the restaurant sector. Scandinavian Journal of Psychology, 49(1), 59-68. doi:10.1111/j.1467-9450.2007.00602.x

McCarthy, P., Sheehan, M., \& Kearns, D. (1995). Managerial styles and their effects on employees health and well-being in organizationsundergoing restructuring. Report of Worksafe Australia Brisbane: Griffirht University.

Mikkelsen, E.G., \& Einarsen, S. (2001). Bullying in Danish work-life: Prevalence and healthcorrelates. European Journal of Work and Organizational Psychology, 10(4), 393-413. doi:10.1080/13594320143000816

Miner, K., \& Eischeid, A. (2012). Observing incivility toward coworkers and negative emotions: Do gender of the target and observer matter? Sex Roles, 66, 492-505. doi:10.1007/s11199-011-0108-0

Moreno-Jimenez, B.,Rodriguez-Muñoz, A., Martínez Gamarra, M., \& Gálvez-Herrer, M. (2007). Assessing Workplace Bullying: Spanish Validation of a Reduced Version of the Negative Acts Questionnaire. The Spanish Journal of Psychology, 10(2) 449-457. doi:10.1017/s1138741600006715

Namie, G., \& Namie, R. (2000). The bully at work. What you can do to stop the hurt and reclaim the dignity on the job. Naperville: Sourcebooks, Inc.

Notelaers, G. (2011). Workplace Bullying: a risk control perspective. PhD Thesis Faculty of Psychology, University of Bergen, Norway.
Notelaers, G., \& Einarsen, S. (2013) The world turns at 33 and 45: Defining simple cutoff scores for the Negative Acts Questionnaire-Revised in a representative sample. European Journal of Work and Organizational Psychology, 22(6), 670-682. doi:10.1080/1359432X.2012.690558

Olweus, D. (1994). Bullying at school: Long-term outcomes for the victims and an effective schoolbased intervention program. In L.R. Huesmann (Ed.), Aggressive behavior: Current perspectives (pp. 97-130). New York: Plenum.

Omari, M. (2007). Towards dignity and respect at work: An exploration of bullying in the public sector. Doctorate dissertation, Edith Cowan University, Perth, Western Australia. https://ro.ecu.edu.au/theses/45

Ortega, A., Hogh, A., Pejtersen, J.H., \& Olsen, O. (2009). Prevalence of workplace bullying and risk groups: A representative population study. International Archives of Occupational and Environmental Health, 82(3), 417-426. doi:10.1007/s00420-008-0339-8

Painter, K. (1991). Violence and vulnerability in the workplace: psychosocial and legalimplications. In M.J. Davidson \& J. Earnshaw (Eds.), Vulnerable workers: psychosocial and legal issues (pp. 160178). New York: John Wiley \& Sons.

Paoli, P. (1997). Second European Survey on Working Conditions in the European Union (Vol. EF/97/26): European Foundation for the Improvement of Living and Working Conditions.

Petrović, I.B., Vukelić, M., \& Čizmić, S. (2017). Rocking at 81 and Rolling at 34: ROC Cut-Off Scores for the Negative Acts Questionnaire-Revised in Serbia. Frontiers in Psychology, 7(A2058). 1-13. doi:10.3389/fpsyg.2016.02058

Rayner, C., \& Hoel, H. (1997). A summary review of literature relating to workplace bullying. Journal of Community and Applied Social Psychology, 7(3), 181-191. doi: 10.1002/(SICI)10991298(199706)7:3<181::AID-CASP416>3.0.CO;2-Y

Rosander, M., \& Blomberg, S. (2019). Levels of workplace bullying and escalation - a new conceptual model based on cut-off scores, frequency and self-labelled victimization. European Journal of Work and Organizational Psychology, 28(6), 769783. doi:10.1080/1359432X.2019.1642874

Salin, D. (2003). Ways of explaining workplace bullying: A review of enabling, motivating and precipitating structures and processes in the work environment. Human relations, 56(10), 1213-1232. doi: 10.1177/00187267035610003

Salin, D. (2018). Workplace Bullying and Gender: An Overview of Empirical Findings. In: P. D'Cruz, E. Noronha, C. Caponecchia, J. Escartín, D. Salin, \& M. Tuckey (Eds.), Dignity and Inclusion at Work. Handbooks of Workplace Bullying, Emotional Abuse and Harassment (pp. 1-31). A3 Book chapter, Singapore: Springer. 
Salin, D., \& Hoel, H. (2011). Organisational causes of workplace bullying. In S. Einarsen, H. Hoel, D. Zapf, \& C. Cooper (Eds.), Bullying and harassment in the workplace: Developments in theory, research, and practice (pp. 227-244). Boca Raton, FL: CRC Press.

Skuzińska, A., Plopa, M., \& Plopa, W. (2020). Bullying at Work and Mental Health: The Moderating Role of Demographic and Occupational Variables. Advances in Cognitive Psychology, 16(1), 13-23. doi:10.5709/acp-0280-9

Taboroši, S., Strukan, E., Poštin, J., Konjikušić, M., \& Nikolić, M. (2020). Organizational commitment and trust at work by remote employees. Journal of Engineering Management and Competitiveness, 10(1), 48-60.

The Bergen Bullying Research Group - BBRG (n.d.). International Database on the Prevalence and risk factors of Bullying at work, IDPB. Retrieved from http://www.uib.no/rg/bbrg

Tong, S.F., \& Low, W.Y. (2012). Public health strategies to address Asian men's health needs. Asia Pacific Journal of Public Health, 24(4), 543-555. doi: $0.1177 / 1010539512452756$

Tsuno, K., Kawakami, N., Tsutsumi, A., Shimazu, A., Inoue, A., Odagiri, Y., Yoshikawa, T., Haratani, T., Shimomitsu, T., \& Kawachi, I. (2015).

Socioeconomic Determinants of Bullying in the Workplace: A National Representative Sample in Japan. PloS One, 10(3): e0119435. Published online 2015 Mar 9. doi: 10.1371/journal.pone.0119435.

Van de Vliert, E., Einarsen, S., \& Nielsen, M.B. (2013). Are national levels of employee harassment cultural covariations of climato-economic conditions? Work \& Stress, 27(1), 106-122. doi:10.1080/02678373.2013.760901

Vartia, M. (1996). The sources of bullying: Psychological work environment and organizational climate. European Journal of Work and Organizational Psychology. 5(2), 203-214. doi:10.1080/13594329608414855

Vukelić, M., Čizmić, S., \& Petrović, I.B. (2018). Acceptance of Workplace Bullying Behaviors and Job Satisfaction: Moderated Mediation Analysis With Coping Self-Efficacy and Exposure to Bullying. Psychological Reports, 122(5), 1883 1906. doi:10.1177/0033294118793985

Vukelić, M., Čizmić, S., Petrović, I.B., Tenjović, L., \& Giorgi, G. (2015). Psychometric properties of the Serbian version of the Negative Acts Questionnaire Revised. Psihologija, 48(1), 19-33.

Vukelić, M.B. (2015). Understanding of workplace bullying through analysis of perception of negative acts (Doctoral Dissertation). University of Belgrade. Faculty of Philosophy, Serbia.

Yildirim, A., \& Yildirim, D. (2007). Mobbing in the workplace by peers and managers: mobbing experienced by nurses working in healthcare facilities in Turkey and its effect on nurses. Journal of Clinical Nursing, 16(8), 1444-1453. doi:10.1111/j.1365-2702.2006.01814.x

Zapf, D., Einarsen, S., Hoel, H., \& Vartia, M. (2003). Empirical findings on bullying in the workplace. In S. Einarsen, H. Hoel, D. Zapf \& C. L. Cooper (Eds.), Bullying and emotional abuse in the workplace. International perspectives in research and practice (pp. 103-126). London: Taylor \& Francis.

Zapf, D., Escartín, J., Einarsen, S., Hoel, H., \& Vartia, M. (2011). Empirical findings on prevalence and risk groups of bullying in the workplace, in S. Einarsen, H. Hoel, D. Zapf, \& C.L. Cooper (Eds.), Bullying and Harassment in the workplace: Developments in Theory, Research, and Practice, 2nd ed. (pp. 75-105). Boca Raton, FL: CRC Press.

\title{
EFEKTI RAZLIČITIH KONTROLNIH VARIJABLI NA NASILJE NA RADNOM MESTU U ORGANIZACIJAMA U SRBIJI
}

\begin{abstract}
U radu su dati rezultati istraživanja uticaja šest kontrolnih varijabli na dimenzije nasilja na radnom mestu i ajtem maltretiranja. Kao kontrolne varijable korišćeni su: Pol ispitanika, Godine starosti ispitanika, Obrazovanje ispitanika, Nacionalno poreklo preduzeća, Vlasnička struktura preduzeća i Veličina preduzeća (broj zaposlenih). Istraživanje je realizovano putem ankete sa ispitanicima, a ispitanici su bili zaposleni u organizacijama u Srbiji, na različitim hijerarhijskim nivoima. Uzorak je obuhvatio 536 upitnika. Analiza je izvršena preko t-test-a nad prosečnim ocenama dimenzija nasilja na radnom mestu i ajtemom maltretiranja, a prema navedenim kontrolnim varijablama. Pokazalo se da nasilje na radnom mestu nije prisutno u velikoj meri u organizacijama u Srbiji, ali je ipak veće nego u nekim visokorazvijenim zemljama. Veličina preduzeća (broj zaposlenih) je identifikovana kao jedini, a samim tim, i veoma značajan faktor pojave nasilja na radnom mestu u organizacijama u Srbiji. Nasilje na radnom mestu je više izraženo u velikim kompanijama nego u malim kompanijama. U radu je diskutovana ova pojava.
\end{abstract}

Ključne reči: Nasilje na radnom mestu; Maltretiranje; Kontrolne varijable; Veličina preduzeća; Srbija. 